\title{
Organizational Justice as Mediator of the Discretionary Human Resource Practice-Organizational Citizenship Behavior Relationship: Evidence from Enterprises in China
}

\author{
San Qing Wu, Jia Xiao \\ Management School of Jinan University, Guangzhou, China \\ Email: xiaojiaxlwb@sina.com
}

Received 8 September 2014; revised 10 October 2014; accepted 5 November 2014

Academic Editor: Charbel J. C. Jabbour, UNESP-Sao Paulo State University, Bauru, Sao Paulo State, Brazil

Copyright (C) 2014 by authors and Scientific Research Publishing Inc.

This work is licensed under the Creative Commons Attribution International License (CC BY). http://creativecommons.org/licenses/by/4.0/

(c) (i) Open Access

\begin{abstract}
Organizational citizenship behavior (OCB) is one kind of extra-role behavior beyond formal role descriptions which can be conducted to enforce company's competency to copy with external competitive pressures as well as internal flat organizational hierarchies. This research builds a mediating model to examine the mediating effects of organizational justice between discretionary human resource practice (HRP) and organizational citizenship behavior based on the social exchange theory and the organizational justice theory. The research illustrates how the different dimensions of discretionary HRP affects employee's OCB through organizational justice. It statistically tests the data form 227 employees in 10 enterprises with correlation analysis, structural equation modeling and other statistical methods. The results show that all the selective staffing, promotional opportunities, performance management and participate decision making in the discretionary HRP have positive impacts on the OCB. Besides, it indicates that organizational justice mediates the relationship between discretionary HRP and OCB. Thus, organization can promote employee's OCB through enforcing its discretionary HRP as well as enhancing perceived organizational justice. The exposure of the relationships between discretionary HRM practice, organizational justice and OCB is beneficial to build sustainable HRM system and help enterprises to establish sustainable competitive competence.
\end{abstract}

\section{Keywords}

Human Resource Practice, Organizational Justice, Organizational Citizenship Behavior 


\section{Introduction}

With increasingly fierce competition and impacts of technological changes, modern enterprises are facing more complex external environment, especially for Chinese enterprises which are encountering with opportunities brought by emerging economic. Besides, it is difficult to define exactly the role of employee, since the scope of job responsibility is extending recent years and the focus of employee performance is changing from task performance to organizational citizenship behaviors. Some studies also acknowledge organizational outcomes, which are broader than financial outcomes [1]. In order to cope with layoffs, flat organizational structure and competitive pressures, managers of enterprises consider to utilize human resource practices to encourage employees to involve in voluntary extra-role behaviors [2] [3]. Even though researchers have recognized the significant function of human resources practice to stimulate employees' organizational citizenship behaviors, there is no conclusion about the mechanism of this relationship. Additionally, relative empirical research is rare and limited.

This essay tries to explore the relationship between discretionary human resource practice and employee's organizational citizenship behaviors with the mediator of organizational justice. It finds that discretionary human resource practice which undertaken by enterprises is beneficial to improve employee's organizational justice and helpful to enforce employees to take part in organizational citizenship behaviors. By using samples of Chinese enterprises, this study figures out the relationship and mechanism between these core conceptions in Chinese situation and establishes a structured equation model to describe it. It is believed to contribute to provide useful recommendations for enterprise managers to combine and manage human resource practices.

\section{Literature Review}

\subsection{Discretionary Human Resource Practice}

According to Wright \& Boswell (2002) [4], human resource practice (HRP) refers to a range of policy and methodology which might influence employee's attitude, behavior and individual performance. Ostroff \& Bowen (2000) believe human resource practice is one of critical factors that encourage employees to work to support organizational strategic vision and improve organizational performance. There are several different viewpoints about categories of HRP, such as high-commitment HRP, high-performance HRP, high-involved HRP and discretionary HRP [5]-[8].

Discretionary human resource practice is one type of human resource practice which emphasizes the importance of human capital investment from strategic level. It is defined as one kind of voluntary and optional investment to employees to cope with external environmental changes and competition pressure, including training, paying for performance, performance management, promotional management, selective staffing, developmental opportunities, decision making and participation [8].

Previous studies show that discretionary human resource practice is contributive to improve information sharing, cooperating, and individual development. It also benefits for enterprises to achieve sustainable competitive strengths and better cope with change able external environment [3]. According to Hayton (2004) [8] and Gavino (2012) [9], this essay divides the discretionary HRP as four dimensions including selective staffing, promotional opportunities, performance management and participation in decision making. It is different from efficiency based HRM practice including high performance human resource practice, which would bring negative externality to employees on psychological, social and work related health aspects [10].

\subsection{Employee Organizational Citizenship Behavior}

Organizational citizenship behavior (OCB) is a series of extra role behaviors and attitudes which are beneficial to improve organizational performance even though they are not forced or requested to undertake according to contracts or job responsibility [11] [12]. Previous researchers find out OCB is influenced by employee satisfaction, organizational commitment, perceived support and organizational justice [13] [14].

Some researchers believe the conception of OCB can be divided as five dimensions such as altruism, conscientiousness, courtesy, sportsmanship and civic virtue (Organ, 1988). Others argue to divide OCB's dimensions according to different directions of benefits [15] [16]. For example, the organizational behaviors which are directed at other individuals in the workplace are defined as organizational citizenship behavior- individual (OCBI). And OCBO refers to the organizational citizenship behavior which is directed at organization itself. In 
this essay, organizational citizenship behavior is divided as two major dimensions including OCBI and OCBO.

It attracts researchers' interests and concentrations that how to stimulate, cultivate and manage employee's organizational citizenship behaviors, especially in recent years. Many of them provide several convincing theories such social exchange theory. It assumes that positive human resource practice might trigger positive employee attitude and behavior as an exchange procedure. For example, Podsakoff et al. (2000) [17] believe human resource practice is one of efficient tools to stimulate employee organizational citizenship behavior. Other researchers prefer to consider perceived organizational support, perceived organizational justice and employee satisfaction as mediators to explore the relationship between human resource practice and organizational citizenship behavior [18] [19]. Even through studies related to discretionary human resource practice are limited, there are still some researchers make contributive conclusions. Gavino et al. (2012) [9] consider perceived organizational support (POS) as the mediator factor in the relationship between discretionary human resource practice, traditional human resource practice, employee organizational citizenship behavior and customer-oriented commitment. Moreover, it confirms a positive relationship between discretionary HRP and OCB.

Based on critical reviews of previous studies, this essay believes discretionary human resource practice is a positive predictor of employee's organizational citizenship behavior, since it is a kind of optional and voluntary investment which is undertaken by enterprises. Therefore it is proper and reasonable to trigger employee's positive psychological perception and attract employees to increase actual inputs such as engaging in extra role behaviors.

H1: Discretionary human resource practice plays as a positive predictor of employee's organizational citizenship behavior.

\subsection{Organizational Justice}

Organizational justice is firstly promoted by Adams to emphases the importance of equivalence between individual inputs and outputs. After that, Thibaut and Walker (1975) provide to add procedural justice to evaluate the justice issues in the procedure. Moreover, Greenbery (1993) argues to extend the organizational justice framework by extracting interactional justice from procedural justice. Nowadays, the three-dimension framework achieves major researchers' recognition. In this research, organizational justice refers to employee's perceived organizational justice and is divided as three dimensions including procedural justice, distributive justice and interactional justice. Among them, distributive justice is determined by the justice perception of distributive outcomes; procedural justice refers the perceived justice of distribution procedure; and interactional justice describes the justice perception of interpersonal activities in the distribution procedure.

It is believed and examined that organizational citizenship behavior is largely encouraged by perceived organizational justice [20]. Lambert and Hogan (2013) [21] compare the influences of distributive justice and procedural justice on the organizational citizenship behavior and find out that relationship between procedural justice and OCB is more intensive. Other researchers devote to figure out the mechanism of relationship between organizational justice and OCB. For example, Sun and Chow (2013) [22] examine the mediating role of leadermember exchange relationship between procedural justice and organizational citizenship behavior. Van Dijken and De Cremer (2012) [23] consider leadership type as mediator of relationship between procedural justice and organizational citizenship behavior. Frenkel et al. (2012) [3] study the relationship between human resource practice and extra role behavior examining the mediators of organizational identity, distributive justice and procedural justice.

This research holds the view that employees will tend to present positive attitude towards their work performance, outcomes and supervisor once they are perceived to be treated in a justice manner. Especially when considering about organizational citizenship behavior, it is typical extra-role behavior which is convenient for employees to adjust and balance the perceived justice or injustice feeling. Therefore it is proposed as hypotheses below.

H2: Organizational justice plays as mediator between discretionary human resource practice and employee organizational citizenship behavior.

H2a: There is a positive relationship between discretionary human resource practice and organizational justice.

H2b: There is a positive relationship between organizational justice and organizational citizenship behavior.

The theoretical framework of this article is demonstrated in the Figure 1 with all the hypotheses above. 


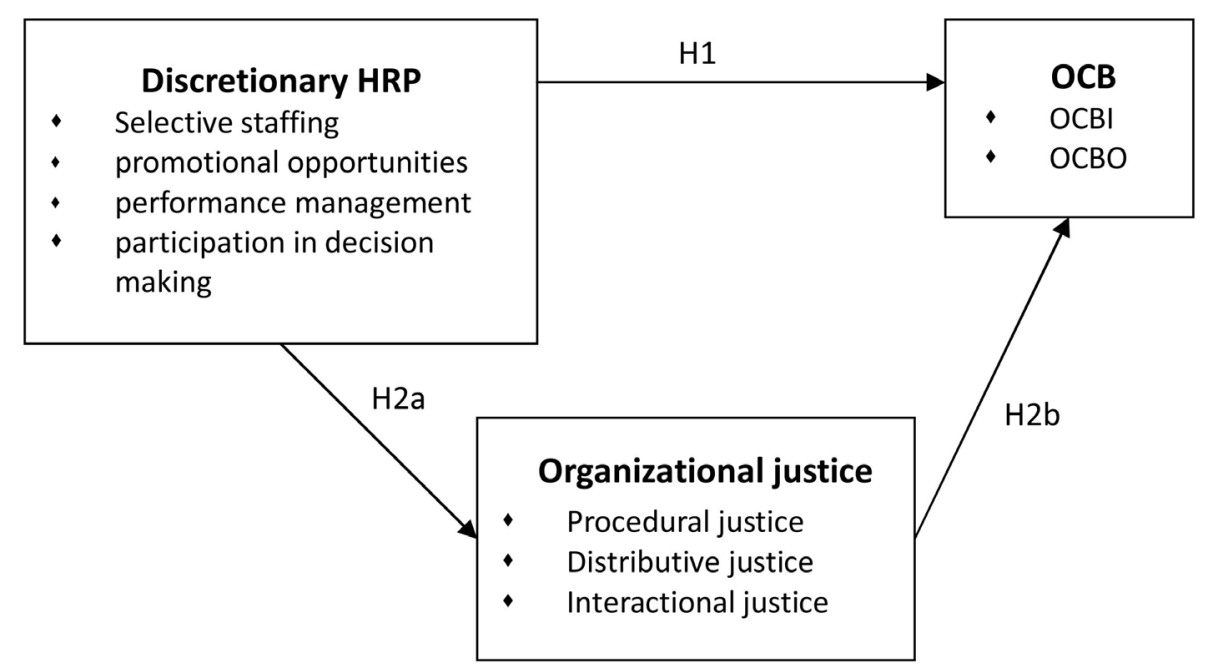

Figure 1. Theoretical framework of this research.

\section{Research Methodology}

\subsection{Research Method}

In order to figure out the mechanism between discretionary human practice and employee organizational citizenship behavior and examine the mediating effect of organizational justice, a correlational research design is employed. And the data were collected through self-reported questionnaires with five-point Likert scales. After interviewing human resource managers from 23 enterprises in Guangzhou, Shenzhen, Foshan and Dongguan in the south of China, 10 enterprises are selected since they are featured with discretionary human resource practice. 227 of 300 employee questionnaires that were distributed are returned, for a response rate of $75.67 \%$.

\subsection{Data Collection}

Of the samples used in this research, $84.6 \%$ of employees come from private companies, $10 \%$ come from state-owned companies and $5.4 \%$ are foreign enterprise employees. $28.2 \%$ of companies have less than 100 employees, 32.2\% have firm size between 100 to 500 employees and 33.9\% own more than 500 employees. 102 men (44.9\%) and 125 women (55.1\%) participate in the research that $50.2 \%$ are managers and supervisors while $49.8 \%$ are clerical and production workers. The average organizational tenure is 2.48 years $(S D=1.242)$. The samples cover a wide range of sectors including manufacture, finance, information and service industries.

\subsection{Measurement of Variables}

This research measured all the variables with five-point Likert scales which are adapted from established measures ranging from 1 (strongly disagree) to 5 (strongly agree).

\subsubsection{Discretionary Human Resource Practice}

This research takes advantage of framework of Gavino et al. (2012) [9] that categorized discretionary human resource practice as four dimensions. There are 16 items selected from original scales with significantly acceptable factor loadings that represent selective staffing, promotional opportunities, performance management and decision making participation (e.g., "the enterprise has strict procedure and evaluation system for its recruitment and hiring activities").

\subsubsection{Organizational Citizenship Behavior}

This research uses the measurement scale which is adapted from research of Jiing-Lih et al. (2004) [24] to measure employee's organizational citizenship behavior. They conclude several items of organizational citizenship behaviors which better represent Chinese employee's attitudes and behaviors. Therefore it is appropriate to be used in this research. This part of questionnaire includes 10 items, such as "I devote to improve organiza- 
tion’s positive image" and "I would like to help my colleague in and out of workplace".

\subsubsection{Organizational Justice}

In this research, we measure organizational justice with Moorman’s justice scale (1991) [25]. He divides organizational justice with three dimensions including distributive justice, procedural justice and interactional justice. 15 items of scales are selected to evaluate employees' perceived organizational justice (e.g. "my supervisor always show respect to me".

\subsection{Validity and Reliability of Data}

The reliability of data is tested before empirical analysis with the use of Cronbach's alpha (if the alpha value is over 0.5, it is appropriate to present consistency). In this research, the Cronbach's alpha value of discretionary human resource practice is 0.823 , organizational citizenship behavior is 0.861 and organizational justice is 0.915 . The hypotheses are tested by cross-sectional data with the use of SPSS 19.0 and AMOS 20.0. Besides, correlation analysis matrix and structural equation model will be generated as outcomes to make conclusion.

\section{Results}

\subsection{Descriptive Statistics and Correlations}

Table 1 shows the descriptive statistics and Pearson correlation between variables. The data from table 1 demonstrates that there are positive relationships between four dimensions of discretionary human resource practice and organizational citizenship behavior. Comparing with OCBO, employees present more organizational citizenship behaviors which are directed at colleagues at the workplace. And the positive collections between OCBI and selective staffing, promotional opportunities, performance management (ranging from 0.50 to 0.643 ) is higher than correspondence relationship between OCBO and these discretionary HRP (ranging from 0.484 to 0.633). While there are great and significant correlations between organizational justice and OCBO $(r=0.75$, 0.753 and 0.75 separately). In additional, nearly all of correlations between variables are significant which support $\mathrm{H} 1$ proposed before.

\subsection{Tests of Hypotheses}

In order to build the structural equation, we assessed model fit with multiple goodness-of-fit indices, including the comparative fit index (CFI), root mean square error of approximation (RMSEA) [26] [27]. This model's RMSEA value $<0.06$ and CFI value $\geq 0.95$. Therefore it is treated as indicative of good-fitting model. The detail of structural equation is illustrated in the Figure 2.

In this model, the coefficient of the path from discretionary human resource practice to employee organizational citizenship behavior is significant, $\beta=0.39, \mathrm{p}<0.05$. The coefficient of the path from discretionary human resource practice and organizational justice is significant, $\beta=0.92, \mathrm{p}<0.01$ and as is the coefficient of the path from organizational justice to employee organizational citizenship behavior, $\beta=0.62, \mathrm{p}<0.01$. This is a consistent result with hypothesis 1 and it indicates that organizational justice partly mediates the relationship between discretionary human resource practice and employee organizational citizenship behavior. Therefore, the hypothesis 2 is partly supported. In conclusion, these results offer support for hypotheses proposed before.

\section{Discussion}

The main objective of this research is to investigate the relationship between discretionary human resource practice and employee organizational citizenship behavior and examine the mediating role of organizational justice. According to this research, two basic hypotheses are formulated and some useful findings are discussed below.

Firstly, discretionary human resource practice has a significant and positive correlation with employee's organizational citizenship behaviors. For example, the selective staffing, promotional opportunities, performance management and participation in the decision making can positively stimulate employees to undertake extra role behaviors which are beneficial to improve organizational performance or helpful to keep harmony colleague relationships. This conclusion is in consistent with Gavino's finding in 2012 [9]. In particular, this research examines the inner relationship between four dimensions of discretionary human resource practice and two aspects 
Table 1. Descriptive statistics and inter correlations.

\begin{tabular}{|c|c|c|c|c|c|c|c|c|c|c|c|c|c|c|c|c|}
\hline & & Mean & SD & 1 & 2 & 3 & 4 & 5 & 6 & 7 & 8 & 9 & 10 & 11 & 12 & 13 \\
\hline 1 & Firm size & 2.15 & 1.041 & 1 & & & & & & & & & & & & \\
\hline 2 & Position & 1.79 & 0.910 & $0.416^{* *}$ & 1 & & & & & & & & & & & \\
\hline 3 & Gender & 1.56 & 0.498 & -0.066 & 0.079 & 1 & & & & & & & & & & \\
\hline 4 & $\begin{array}{l}\text { Educational } \\
\text { level }\end{array}$ & 2.56 & 1.077 & 0 & -0.026 & 0.094 & 1 & & & & & & & & & \\
\hline 5 & $\begin{array}{l}\text { Organizational } \\
\text { tenure }\end{array}$ & 2.48 & 1.242 & $0.254^{* *}$ & $0.436^{* *}$ & -0.042 & $-0.613^{* *}$ & 1 & & & & & & & & \\
\hline 6 & $\begin{array}{l}\text { Selective } \\
\text { staffing }\end{array}$ & 3.75 & 0.487 & $0.285^{* *}$ & $0.288^{* *}$ & 0.130 & 0.113 & $0.188^{* *}$ & 1 & & & & & & & \\
\hline 7 & $\begin{array}{l}\text { Promotional } \\
\text { opportunities }\end{array}$ & 3.75 & 0.598 & $0.206^{* *}$ & $0.322^{* *}$ & 0.018 & 0.129 & $0.261^{* *}$ & $0.280^{* *}$ & 1 & & & & & & \\
\hline 8 & $\begin{array}{l}\text { Performance } \\
\text { management }\end{array}$ & 3.7 & 0.477 & $0.129^{* *}$ & $0.375^{* *}$ & 0.098 & 0.081 & 0.080 & $0.258^{* *}$ & $0.439^{* *}$ & 1 & & & & & \\
\hline 9 & $\begin{array}{l}\text { Participation } \\
\text { in decision } \\
\text { making }\end{array}$ & 3.42 & 0.461 & 0.110 & $0.182^{* *}$ & 0.077 & $0.220^{* *}$ & -0.047 & $0.334^{* *}$ & $0.390^{* *}$ & $0.416^{* *}$ & 1 & & & & \\
\hline 10 & $\begin{array}{l}\text { Procedural } \\
\text { justice }\end{array}$ & 3.64 & 0.518 & $0.244^{* *}$ & $0.342^{* *}$ & $0.137^{*}$ & 0.030 & 0.110 & $0.402^{* *}$ & $0.453^{* *}$ & $0.530^{* *}$ & $0.399^{* *}$ & 1 & & & \\
\hline 11 & $\begin{array}{l}\text { Interactional } \\
\text { justice }\end{array}$ & 3.69 & 0.574 & $0.161^{*}$ & $0.374^{* *}$ & $0.150^{*}$ & $0.287^{*}$ & -0.037 & $0.312^{* *}$ & $0.488^{* *}$ & $0.561^{* *}$ & $0.456^{* *}$ & $0.617^{* *}$ & 1 & & \\
\hline 12 & $\begin{array}{l}\text { Interactional } \\
\text { justice }\end{array}$ & 3.77 & 0.654 & $0.234^{* *}$ & $0.297^{* *}$ & $0.224^{* *}$ & $0.169^{*}$ & 0.031 & $0.435^{* *}$ & $0.471^{* *}$ & $0.502^{* *}$ & $0.436^{* *}$ & $0.649^{* *}$ & $0.683^{* *}$ & 1 & \\
\hline 13 & OCBI & 3.79 & 0.463 & $0.244^{* *}$ & $0.394^{* *}$ & $0.203^{* *}$ & $0.205^{* *}$ & 0.092 & $0.500^{* *}$ & $0.546^{* *}$ & $0.643^{* *}$ & $0.468^{* *}$ & $0.689^{* *}$ & $0.717^{* *}$ & $0.715^{* *}$ & 1 \\
\hline 14 & ОСВО & 3.72 & 0.458 & $0.211^{* *}$ & $0.413^{* *}$ & $0.242^{* *}$ & $0.136^{*}$ & $0.130^{*}$ & $0.484^{* *}$ & $0.508^{* *}$ & $0.633^{* *}$ & $0.508^{* *}$ & $0.750^{* *}$ & $0.753^{* *}$ & $0.750^{* *}$ & $0.844^{* *}$ \\
\hline
\end{tabular}

Note: ${ }^{* *} \mathrm{p}<0.01,{ }^{*} \mathrm{p}<0.05$.

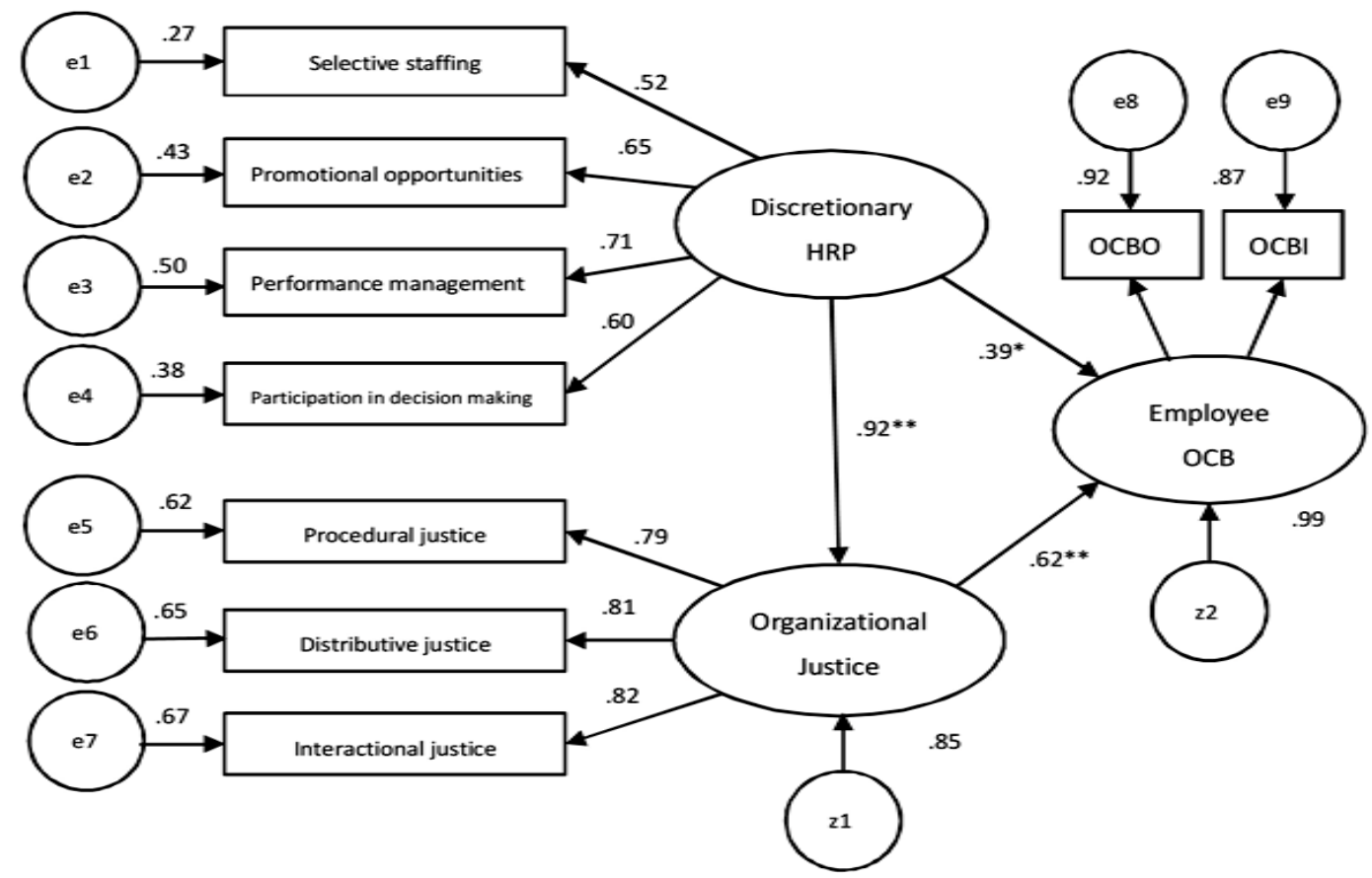

Figure 2. Structural equation of the relationship between discretionary human resource practices, organizational justice and employee organizational citizenship behaviors. Model fit: $\chi^{2}(24 d f)=32.185(p<0.001)$, RMSEA $=0.039$, CFI $=0.994,{ }^{*} \mathrm{p}<0.05 ;{ }^{* *} \mathrm{p}<0.01 ;{ }^{* * *} \mathrm{p}<0.001$. 
of organizational citizenship behavior. It finds that selective staffing, promotional opportunities and performance management are more important to influence organizational citizenship behavior which is directed at individual while participation in decision making is better linked with OCBO. It can be assumed that employees who are obliged with responsibilities to participate in decision making are more likely to serve for organizational objectives and protect organizational images. Therefore, it has positive significance for enterprises in the modern society to invest in human capital proactively, since it is beneficial to improve employee's organizational citizenship behavior and stimulate employees to make contributions to improve organizational performance voluntarily.

The finding about relationship between discretionary human resource practice and organizational citizenship behavior indicates that enterprises should be aware of the critical role of discretionary HRP, build system and emphasis it from strategic level. In the discretionary human resource practice, enterprise should make efforts to improve staff selection procedure, provide better promotional opportunities and give appropriate feedback of employee's performance. They can also encourage employees to participate in decision making, empower employees to take part in formal projects to improve management level. Most important of all, enterprises should make it available for employees to perceive their investment and show adequate respects.

Secondly, the researcher formulates a hypothesis to investigate the mediating effect of organizational justice on the relationship between discretionary HRP and employee OCB. It finds out that the so-called discretionary human resource practice could promote employee's organizational citizenship behaviors by improving employee's perceived organizational justice. It is also helpful to clarify the relationship between discretionary HRP and OCB in the modern business environment. It finds that organizational justice has greater influence on OCBO than OCBI. It might be contributive that employees are more sensitive about organizational justice from organization level. Therefore, organizational justice is more significantly beneficial to improve organizational citizenship behaviors which are directed at organization. It also indicates that organizational justice is relative to several positive feelings including organizational loyalty, organizational identity, and perceived organizational support. Besides, employees who are motivated by those positive feelings are more likely to contribute to organizational objective and help colleagues.

In additional, enterprises should be notice to form strict rewarding and punishment system to manage employee's performance and better motivate employees to undertake extra-role behaviors. Some evaluations and feedbacks need to be provided to ensure employee's fairness perception and recognition of positive discretionary human resource policies. Communication channels are essentially been built to promote employee's perceived organizational justice. Finally, open and fair atmosphere will be helpful to increase employee satisfaction and stimulate them to take part in more organizational citizenship behaviors which aims at improving organizational performance.

\section{Conclusion, Limitations and Future Research}

Based on the results of the study, it can be concluded that discretionary human resource practice is positively related to employee organizational citizenship behavior and there is a partial mediating effect of organizational justice of the relationship between discretionary HRP and employee OCB. It is demonstrated that enterprises could improve employee organizational citizenship behavior by undertaking discretionary human resource practice and the HRP's function might be partially built on the perceived organizational justice. It is believed to be helpful to investigate discretionary human resource practice situations in enterprises form South of China and make contribution to improve human resource management level. Firstly, the results of study are beneficial to guide enterprises to make human resource related strategic decision, such as providing diverse training courses, empowering employees to participate in decision making. Secondly, the results of study contribute to establish managerial discipline which emphasizes the importance of human resource capital. Thirdly, take advantages of discretionary HRM practice and improve employee's organizational justice will help enterprises to hold competitive position and develop sustainably.

However, there are still some limitations about the research. First, the data is collected through self-reporting questionnaire. For example, the discretionary human resource practice, organizational citizenship behavior and perceived organizational justice are measured according to the respondents' own attitudes. In the future research, it could be improved by asking respondent's superior and colleague to answer relative questionnaires and measuring required items more accurately. Second, the selected enterprises are featured with high investment in the 
discretionary human resource practice. Therefore employees often have high evaluations about enterprises' human resource practice. Future researchers could consider expanding the sample range and achieving more accurate results of both high and low discretionary HRP as well as their mechanisms. Third, this research is based on social exchange theory and investigates the mediating effect of organizational justice. However, there are still other factors which might be critical to influence employee organizational citizenship. In the future research, organizational support, job satisfaction and other dimensions could be added into the framework to understand the relationship between discretionary HRP and OCB.

\section{References}

[1] Kramar, R. (2014) Beyond Strategic Human Resource Management: Is Sustainable Human Resource Management the Next Approach? International Journal of Human Resource Management, 25, 1069-1089. http://dx.doi.org/10.1080/09585192.2013.816863

[2] Parker, S.K., Bindl, U.K. and Strauss, K. (2010) Making Things Happen: A Model of Proactive Motivation. Journal of Management, 36, 827-856. http://dx.doi.org/10.1177/0149206310363732

[3] Frenkel, S., Restubog, S.L.D. and Bednall, T. (2012) How Employee Perceptions of HR Policy and Practice Influence Discretionary Work Effort and Co-Worker Assistance: Evidence from TWO Organization. International Journal of Human Resource Management, 23, 4193-4210. http://dx.doi.org/10.1080/09585192.2012.667433

[4] Wright, P.M. and Boswell, W.R. (2002) Desegregating HRM: A Review and Synthesis of Micro and Macro Human Resource Management Research. Journal of Management, 28, 247-276.

[5] Arthur, J.B. (1994) Effects of Human Resource Systems on Manufacturing Performance and Turnover. The Academy of Management Journal, 37, 670-687. http://dx.doi.org/10.2307/256705

[6] Appelbaum, E., Bailey, T., Berg, P., et al. (2000) Manufacturing Advantage: Why High Performance Systems Pay Off. Cornell University Press, Ithaca, NY.

[7] Vandenberg, R.J., Richardson, H.A. and Eastman, L.J. (1999) The Impact of High Involvement Work Processes on Organizational Effectiveness: A Second-Order Latent Variable Approach. Group \& Organization Management, 24, 300-339. http://dx.doi.org/10.1177/1059601199243004

[8] Hayton, J.C. (2004) Strategic Human Capital Management in SMEs: An Empirical Study of Entrepreneurial Performance. Human Resource Management, 42, 375-391. http://dx.doi.org/10.1002/hrm.10096

[9] Gavino, M.C., Wayne, S.J. and Erdogan, B. (2012) Discretionary and Transactional Human Resource Practices and Employee Outcomes: The Role of Perceived Organizational Support. Human Resource Management, 51, 665-686. http://dx.doi.org/10.1002/hrm.21493

[10] Mariappanadar, S. (2012) Harm of Efficiency Oriented HRM Practices on Stakeholders: An Ethical Issue for Sustainability. Society and Business Review, 7, 168-184.

[11] Bateman, T.S. and Organ, D.W. (1983) Job Satisfaction and the Good Soldier: The Relationship between Affect and Employee “Citizenship”. The Academy of Management Journal, 26, 587-595. http://dx.doi.org/10.2307/255908

[12] Organ, D.W. (1988) Organizational Citizenship Behavior: The Good Soldier Syndrome. Lexington Books, Lexington.

[13] Lavelle, J.J., Brockner, J., Konovsky, M.A., et al. (2009) Commitment, Procedural Fairness, and Organizational Citizenship Behavior: A Multifoci Analysis. Journal of Organizational Behavior, 30, 337-357. http://dx.doi.org/10.1002/job.518

[14] Wang, G. (2011) The Study on Relationship between Employees’ Sense of Organizational Justice and Organizational Citizenship Behavior in Private Enterprises. Energy Procedia, 5, 2030-2034. http://dx.doi.org/10.1016/j.egypro.2011.03.350

[15] Williams, L.J. and Anderson, S.E. (1991) Job Satisfaction and Organizational Commitment as Predictors of Organizational Citizenship and In-Role Behaviors. Journal of Management, 17, 601-617. http://dx.doi.org/10.1177/014920639101700305

[16] Aryee, S., Budhwar, P.S. and Zhen, X.C. (2002) Trust as a Mediator of the Relationship between Organizational Justice and Work Outcomes: Test of a Social Exchange Model. Journal of Organizational Behavior, 23, 267-285.

[17] Podsakoff, P.M., Mackenzie, S.B., Paine, J.B., et al. (2000) Organizational Citizenship Behaviors: A Critical Review of the Theoretical and Empirical Literature and Suggestions for Future Research. Journal of Management, 26, 513-563. http://dx.doi.org/10.1177/014920630002600307

[18] Zhang, H. and Agarwal, N.C. (2009) The Mediating Roles of Organizational Justice on the Relationships between HR Practices and Workplace Outcomes: An Investigation in China. International Journal of Human Resource Management, 20, 676-693. http://dx.doi.org/10.1080/09585190802707482 
[19] Weia, Y.-C., Hanb, T.-S. and Hsu, I.-C. (2010) High-Performance HR Practices and OCB: A Cross-Level Investigation of a Causal Path. International Journal of Human Resource Management, 21, 1631-1648. http://dx.doi.org/10.1080/09585192.2010.500487

[20] Organ, D.W. and Ryan, K. (1995) A Meta-Analytic Review of Attitudinal and Dispositional Predictors of Organizational Citizenship Behavior. Personnel Psychology, 48, 775-802. http://dx.doi.org/10.1111/j.1744-6570.1995.tb01781.x

[21] Lambert, E.G. and Hogan, N.L. (2013) The Association of Distributive and Procedural Justice with Organizational Citizenship Behavior. Prison Journal, 93, 313-334. http://dx.doi.org/10.1177/0032885513490491

[22] Sun, L.-Y., Chow, I.H.S., Chiu, R.K. and Pan, W. (2013) Outcome Favorability in the Link between Leader-Member Exchange and Organizational Citizenship Behavior: Procedural Fairness Climate Matters. The Leadership Quarterly, 24, 215-226. http://dx.doi.org/10.1016/j.leaqua.2012.10.008

[23] Van Dijke, M., De Cremer, D., Mayer, D.M., et al. (2012) When Does Procedural Fairness Promote Organizational Citizenship Behavior? Integrating Empowering Leadership Types in Relational Justice Models. Organizational Behavior \& Human Decision Processes, 117, 235-248. http://dx.doi.org/10.1016/j.obhdp.2011.10.006

[24] Farh, J.-L., Earley, P.C. and Lin, S.-C. (1997) Impetus for Action: A Cultural Analysis of Justice and Organizational Citizenship Behavior in Chinese Society. Administrative Science Quarterly, 42, 421-444. http://dx.doi.org/10.2307/2393733

[25] Moorman, R.H. (1991) Relationship between Organizational Justice and Organizational Citizenship Behaviors: Do Fairness Perceptions Influence Employee Citizenship? Journal of Applied Psychology, 76, 845-855. http://dx.doi.org/10.1037/0021-9010.76.6.845

[26] Hu, L. and Bentler, P.M. (1999) Cutoff Criteria for Fit Indices in Covariance Structure Analysis: Conventional Criteria versus New Alternatives. Structure Equation Modeling, 6, 1-55. http://dx.doi.org/10.1080/10705519909540118

[27] Steiger, J.H. (2000) Point Estimation, Hypothesis Testing, and Interval Estimation Using RMSEA: Some Comments and a Reply to Hayduk and Glaser. Structure Equation Modeling, 7, 149-162. http://dx.doi.org/10.1207/S15328007SEM0702 1 
Scientific Research Publishing (SCIRP) is one of the largest Open Access journal publishers. It is currently publishing more than 200 open access, online, peer-reviewed journals covering a wide range of academic disciplines. SCIRP serves the worldwide academic communities and contributes to the progress and application of science with its publication.

Other selected journals from SCIRP are listed as below. Submit your manuscript to us via either submit@scirp.org or Online Submission Portal.
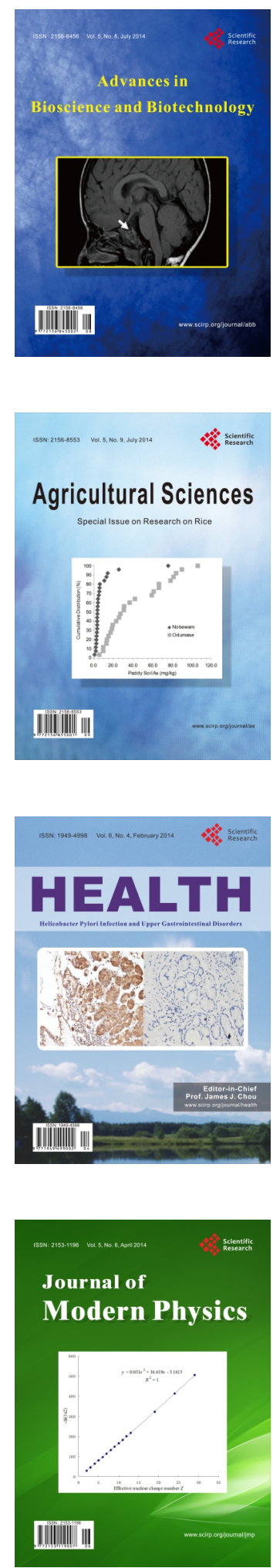
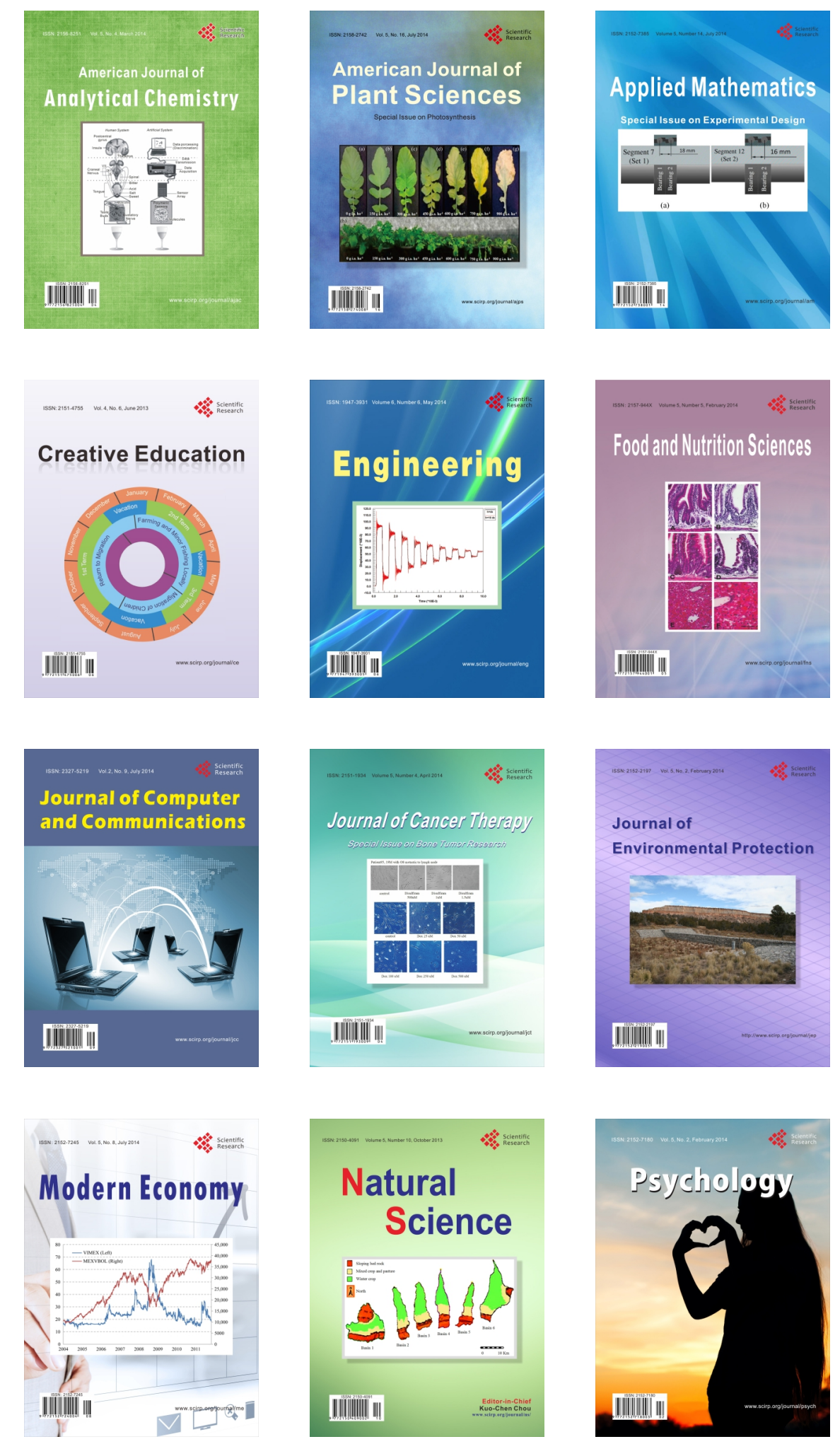